of the Library, which is being developed as a National Library of Science. During the year, the Library was used by 22,000 readers, while the issues on loan of books and periodicals to Government departments, scientific and technical societies, colleges, etc., was 21,000. The Library receives more than 9,000 current periodicals and the contents of these are all indexed, references to these and to other matters now running into millions. There are about 250,000 books in the Library. "The two main functions of the Library," the report says, "may broadly be stated as the acquiring of documents and making them readily available", the latter consisting of cataloguing the volumes, maintaining indexes of their contents, provision of the volumes to readers, loan service, supply of bibliographies, supply of photostat copies, and Library publications. There have been many valuable additions to the collections in the Museum, and during the year under review special exhibitions were arranged illustrating the progress of research at very low temperatures, the scientific aspects of smoke pollution of the atmosphere and the developments in electric illumination.

\section{Overhead Costs in Business Management}

ONE of the most difficult tasks for a business management, whether the concern be large or small, is the adequate control of overhead costs. The usual classification of overhead expenses into salaries, rent, rates and taxes, legal expenses or the like is quite inadequate, because responsibilities cannot be tied up with the expenditure on these items, and generally there is no method of measuring the value obtained from the expenditure. In a valuable and thoughtprovoking report entitled "The Control of Overheads" (Mansfield House, 376 Strand, W.C.2. 5s.), prepared by a committee of the Management Research Groups, the subject is examined with the aim of securing effective control through localization of responsibility. To secure this, the report recommends the division of all overhead expenditure into a series of functions or services, each of which would be in charge of one person, thus permitting the fixation of responsibility. In order to assess the value of the work done by each section of the organization, its cost must be related to the volume of the work done and to the value or quality of that work; and for this purpose various ratios or 'yard sticks' are suggested in the report. The essential requirement is that responsibility for functional costs should be invested in persons, and to ensure that personnel shall cover each of the functions, it is most desirable that an organization chart should be constructed. Budgetary control is an excellent method of reviewing expenses in advance and making comparisons immediately results are available. Costs, however, may be rendered useless as a means of measuring efficiency because of plant working under capacity owing to insufficiency of orders. The report, therefore, recommends that the costs be 'purified' of the cost of idle plant by the abstracting and debiting of all such expenses to a non-productive account, which is carried straight on the trading account.

\section{Economics of Wages and Price Levels}

IN an address before the Economic Reform Club, London, on June 30, entitled "The Economic Reforms Required for Lasting Prosperity and Peace" which has now been issued in pamphlet form (Economic Reform Club, 61 Great Cumberland Place, London, W.1. 9d.), Mr. A. G. McGregor stresses the supreme importance of reform in wages regulation in securing a steady purchasing power of the pound. Heurges that the method of adjusting wages by industrial dispute should be abolished and replaced by direct government control to adjust wages in accordance with the price level. This would in the first instance involve raising wages and salaries to a level which would bring consuming power in step with productive power, and thereafter the wages board would maintain the proper relation between wages and price level. He stresses the point that bankers should be relieved of all responsibility over the general price level and outlines the functions of a rational banking policy designed to accommodate industry and com. merce with the necessary funds but under rules which eliminate any monetary influence on the price level. He contends that if wages and salaries are controlled in the way indicated so as to secure a satisfactory equilibrium between consuming power and productive power, economic liberty is no more affected than individual freedom in general by the ordinary government responsibility for maintaining law and order, and also that the higher wages and internal consuming power would assist the export trade.

\section{Purchasing Power with a Managed Gold Standard}

In a pamphlet entitled "A Managed Gold Standard" (W. Heffer and Sons, Ltd., Cambridge), E. A. Moyer urges that unemployment and economic distress are due to lack of purchasing power. The State's lack of purchasing power has necessitated higher taxes, which have further decreased the citizen's purchasing power. This lack of purchasing power is due to lack of counters, or money, used for exchanging one man's labour for another's, caused by the inability of an inflexible money standard to keep pace with a continuous rise in prices. He advocates accordingly a managed gold standard based on the monopoliza. tion by the State of the note issuing bank of the standard (gold), and the fixation of the standard's money value by an international commission which should revise this value periodically according to the need of the world's productive ability to ensure the standard's flexibility. The managed standard will instantly increase the purchasing power of the State by increasing its right to issue counters without risk of devaluation, and this increased purchasing power by permitting decreased taxation will increase the purchasing power of the citizen as well as thus stimulating industrial and commercial prosperity. Unemployment will be further diminished or elim. inated by the increased ability of the State to initiate public works. The managed gold standard could be introduced if a few countries only agreed to do so, since other countries would be bound to follow. 